\title{
Côte D'Ivoire: From Pre-Colonisation to Colonial Legacy
}

\author{
Jean-Claude Meledje \\ Wibarex Consulting, Sydney
}

\begin{abstract}
With the exceptions of Ethiopia and Liberia, the nations of Black Africa share a common history of colonialism, despite their diversity. Colonialism lasted for about hundred years, having a great impact on African people. This article will focus specifically on Côte d'Ivoire also known as Ivory Coast, a former French colonial country in West Africa. Côte d'Ivoire has experienced a tumultuous regime history under the French colonial power. $C$ ote has also experienced several civil wars, and multiple regime transitions. Over fifty years after the end of French colonialism, the negative effects of French colonialism are persisting or escalating. More importantly, it will demonstrate how the presence of French colonial power in Côte d'Ivoire has left a long-lasting legacy that has severely impacted the development trajectories of contemporary Côte d'Ivoire.
\end{abstract}

\section{INTRODUCTION}

This article aims to examine Côte d'Ivoire's historical trajectories. First it explores the pre-colonial era, showing how colonialism began with Portugal's pursuit of trade and expanded into a rush for territory that peaked in the nineteenth century, with French ruling over a vast territory, claiming they were bringing 'civilization' to this ancient land. The French imposed their culture on every aspect of the Ivorian society. France was set to take advantage of Côte d'Ivoire, as there was already a potential to exploit its rich agricultural economy (McNamara 1989: 87). This article argues that despite the former French colony being independent for 58 years, Côte d'Ivoire is still facing the challenges of the colonial years. It demonstrates how the locals were subjugated, oppressed, manipulated, and killed for the needs of Social Evolution \& History, Vol. 17 No. 1, March 2018 16-33 
French trade, commerce, and colonialism. This article also discusses the key issue of colonial legacy that helps to understand how it still impacts various aspects of the social, cultural, economic, and political development of independent Côte d'Ivoire today.

Côte d'Or (known today as Côte d'Ivoire) has moved through a pre-colonial period to a colonial period and then on to a period of struggle for independence. Côte d'Ivoire had been inhabited since Neolithic times, by people living in primitive and independent farming lives. However, little is known about Côte d'Ivoire's indigenous people and their history prior to France's involvement in colonialism. It is believed that there are records of the first evidence of the existence of humans in Côte d'Ivoire, which dates back to the Palaeolithic era (Zouande 2011).

The historians explain that these people were either displaced by force or willingly absorbed by the ancestors of the contemporary inhabitants of Côte d'Ivoire. The Portuguese, who arrived in Côte d'Ivoire in the fifteenth century, were the first European explorers. France made its initial contact with Côte d'Ivoire at the time, and missionaries landed at the coast of Assinie in 1637 near the Gold Coast, now Ghana. They established a mission in 1687 and built a fort at Assinie in 1701. Although various treaties were signed between French missionaries and local Kings, the interior remained predominantly untouched by Europeans until the nineteenth century.

\section{CÔTE D'IVOIRE'S PRE-COLONIAL HISTORY}

Centuries before European arrival, West Africa was composed of vast regions, of both savannah and forest. The land as well as the people went through key changes as trade links between north and west were established, and the indigenous people were needed to make use of their organizational skills in order to be successful as traders. Islam was also a force of change. Islam was founded in Arabia in the seventh century, and then it quickly spread west. By 750, Islam was well-established in North Africa. As Muslims traders promoted Islam throughout the south, the number of people who adopted Islam significantly increased (Hatt 2003: 6).

There were many states, empires, and kingdoms in early West Africa. Perhaps, the greatest Islamic states were the Mali, Songhai, and Kanem-Bornu Empires. The rain forest kingdoms of Bénin and Kongo were created in the southern areas as non-Islamic states. By the time the Europeans landed in West Africa, many of the residents were citizens of Empires and Kingdoms (Hatt 2003: 7). 
Before the French colonisation, Côte d'Ivoire was a land where property boundaries did not exist. Scholars know only a little about the inhabitants who lived in concentrated communities with distinct practices and traditions. For example, in the savannah regions, trade was dominated by the Dioula who had fled Muslim conversion under the Mali Empire. They were trading gold and kola nuts by the thirteenth century, making Kong in the north a trading as well as an Islamic centre. Small kingdoms held power across the land. Under the leadership of the Ouattara dynasty in the sixteenth century, the Dioula acted as powerbrokers between the rich people from the south and the Mali and Ghana Empires. These pre-colonial empires were part of the Sudanic Empires of West Africa that introduced and disseminated new traditions into Côte d'Ivoire via trade. When the Mali Empire collapsed, Dioula traders were forced to move south in search of new trading opportunities, which also forced southerners to assimilate the Dioula life style (Broussalian 2011).

The Empire of Kong was formed in the early eighteenth century, but their rival Samory Toure destroyed the empire because of Kong's connection with the French. Born in 1830 in Kankan in the south-east (present-day Guinea), Samory was a trader before becoming a soldier. Between 1852 and 1882, he formed the Madinka Empire which eventually stretched as far east as Sakasou (present-day Mali), as far west as Fouta Djalon (present-day Guinea), and, most predominantly, as far north as of (present-day Côte d'Ivoire), where he conquered huge territories between 1893 and 1898 (Beck 2010).

From the late seventeenth to the nineteenth century, the Asante Empire dominated Africa, inflicting wars on neighbouring communities. As a result, many the Akan people from (Ghana) moved to Côte d'Ivoire. Nonetheless, the death of the well-known Asante leader Asantehene Opoku Ware in 1750 triggered a leadership battle that forced Queen Abla Pokou and her allies to abandon their Kingdom and move to the north-central area of today's Côte d'Ivoire, where they formed the Baoulé kingdom. Other groups such as the Mandé and Krou were also forced to migrate from neighbouring countries to Côte d'Ivoire in fear of prosecution and conflicts from the opposing communities and Kingdoms (Zouande 2011).

The exodus of Abla Pokou is such a well-known piece of history of the immigration of the Baoulé people to Côte d'Ivoire that it has been incorporated into Ivorian primary education curriculum. According to the legend, when the Queen and her people reached the shores of the Comoé River, they faced difficulties in their attempt to cross the 
river to reach their destination, Côte d'Ivoire. In order to cross the river, the Queen sacrificed her only son, the Prince, not by killing, but by tribal baptism. This sacrifice was the root of the name 'Baoulé,' originally baouli, meaning 'the child has died.'

During the time that the Asante Empire gained popularity towards the end of the seventeenth century, the Bouna Kingdom emerged as a new power. The Bouna Kingdom was created by Bounkani migrants from the Gold Coast who moved into Côte d'Ivoire. They created a new regional Islamic education centre. Under the watch of the Bouna Kingdom, the social structure was organized in the following order: first, there were the aristocrats involved in slave trade and farm taxes; second, there were the Koulango (modern-day lobi) peasants; and finally, there were the Dioula traders (Conroy 2010).

Until the late nineteeth century, the residents of what was to become Côte d'Ivoire lived a traditional lifestyle, primarily relying on agricultural production. It is important to emphasize that prior to colonization, rich traditional structures existed, Ivorians villagers lived independently, and political life was naturally and internally organized. Despite this, Europeans often assumed the West African forest regions including Côte d'Ivoire had no history, because from the exterior, they became non-organized (Calvocoressi 1991: 496).

\section{THE FRENCH DESIRE FOR COLONIES AND INFLUENCE}

For decades, through a number of theories, scholars have attempted to determine why Europeans had to colonize Africa, asking whether colonization was sparked by a mission to civilize, as the French colonial administrators claimed, or if it occurred for trade reasons, for other economic reasons or simply to benefit European capitalism (Tordoff 2002: 25-26).

For example, a group of scholars such as Vladimir Lenin put forward an economic reason and argued that since many Europeans could not afford to buy goods from the shelves, it became essential for capitalists to look for new buyers in Africa (Lenin 1917). Other scholars, like Ronald Robinson and John Gallengher, took a geopolitical approach, arguing, for example, that in order to maintain its economic status, Great Britain had to seek colonies and dominate trading (Robinson and Gallengher 1961). On the other hand, Henri Brunshwig argued that France was not interested in economic benefit (Brunshwig 1964). As they say in France, les colonies avaient été créées par le métropole et pour le métropole, the colonies have been created by the metropolis and for the metropolis (Tordoff 2002: 26). 
Despite this common belief, Brunshwig insists that France's colonization of Africa was solely based on status. France needed to be seen as a key player at the international level; consequently, it needed to colonize (Brunshwig 1964). Lori Liane Long has also argued that while economic factors might be taken into account, national pride was one of the most important reasons why European colonial rulers embraced colonization. Once the race to colonize begun, the state that 'could obtain the most colonies, convert most people to its enlightened, cosmopolitan culture was seen as the best' (Brunshwig 1964). As has been succinctly observed 'in order to remain/become a great nation, they had to colonize' (Long 1998).

According to Wayne Walker, given the challenges on the European ground, France utilized colonialism to regain its pride. Towards 1890 , a colonial lobby group was established in France with the aim to mobilize Europeans' opinions regarding the roots of the colonial conquest (cited in Ahipeaud 2009: 21).

Peter Calvocoressi argued that Europeans were interested in Africa long before occupation occurred (Calvocoressi 1991: 493). In the case of Côte d'Ivoire, keeping in mind the idea of national pride, grandeur, and power, France decided to send explorers sailing into the unknown land to explore and claim Côte d'Ivoire as a new colony in order to appear grander (Long 1998).

During the seventeenth century, ivory was one of the most desired commodities in Europe. Côte d'Ivoire was rich in ivory due to its large number of African elephants. Although the locals were strongly determined to protect elephants, and opposed the presence of European powers in their territories, the French managed to establish and participated in the ivory trade. As a result, 'by the early $18^{\text {th }}$ century, hunters had virtually wiped out the entire elephant population' in Côte d'Ivoire (Conroy 2010). This suggested that France wanted to colonize Côte d'Ivoire to have access to ivory.

Côte d'Ivoire's wealth of exotic and rare material goods also attracted the French. From the French perspective, the potential profitability of the colony served as a main motivator, and profitability required the development of natural and human resources (what the French colonialists later called the policy of la mise en valeur). When the French planters found cocoa, coffee, banana and palm oil in Côte d'Ivoire, they began cultivating and exporting them back home, which raised French interest in colonization.

As Peter Calvocoressi pointed out, contemporary Africa provided Europeans with things they needed. This included, among others, slaves for plantations in the West and raw materials (Calvocoressi 
1991: 493). In Côte d'Ivoire, France's strategic plan was to transform the territory into the focal point of its political activities in the region, and to receive agricultural produce (Ahipeaud 2009: 23).

Former American Ambassador Francis McNamara argued that, although France expanded its colonial empire in West Africa from the nineteenth century, at the beginning, the French were not interested in colonialism or overseas involvement. It was only when national pride anxiety aroused that the French began their colonial adventures. Like others, McNamara indicated that the French were not in West Africa for financial reasons. From the outset, the primary reasons why the French were dragged into West Africa were politics and national ego. McNamara also argued that France became interested in territorial expansion because as a rising industrial power, it needed ensured markets and raw materials under its own control (McNamara 1989: xiii-xv).

Like other colonized countries in sub-Saharan Africa that served as sources of raw materials for the colonial ruler, Côte d'Ivoire provided most of the low-cost raw materials to France. A French geographical society sums up the point succinctly the following way: 'the new colonies offer markets for raw materials; the means of production, the products lacking in the mother-country,' while prohibiting the colonies from producing or purchasing products from other European powers (Long 1998).

However, as Carlene Edie has persuasively argued, like its European counterparts, France's colonization of Africa including Côte d'Ivoire was constructed on a political basis as well as an economic one. Confronted with chauvinistic competitions and balance-of-power policy, France expressed its political intention to colonize Côte d'Ivoire. Also, faced with massive industrial challenge, France was required to colonize many other African nations like Côte d'Ivoire in order to obtain and manage new markets and sources of raw materials (Edie 2003: 52). In line with the industrial argument, William Tordoff has pointed out that like many European countries, after the industrial revolution France was concerned about how and where to get raw material required for the manufacturing industry (Tordoff 2002: 26).

As anyone who studied the history of France and Côte d'Ivoire would tell, cultural supremacy also provided justification for France's colonization of Africa in general, in order to teach Christianity and French 'civilization'. In return, France planned to take advantage of the colonies including Côte d'Ivoire, as there was already a potential to exploit their rich agricultural economy (McNamara 1989: 87). Similarly, Peter Schaeder argued that France's pronouncement of its mission civilisatrice (civilizing mission) was its justification for the necessi- 
ty for colonialism in Francophone West Africa, including Côte d'Ivoire, over people who were seen as 'backward,' 'ignorant,' 'uncivilized,' 'barbaric,' 'savage' and 'godless heathens' (Schaeder 2004: 58).

\section{FRENCH COLONIAL RULE AND STYLE}

The French Governor Gabriel-Louis Angoulvand commented that colonization 'was not just about exploring the country in order to know it better, but it was about completely conquering the territory in order to contribute to its economic and social development' (Ahipeaud 2009: 23).

Grah Mel describes colonialism as the racism of the colon, colonialist, a term which expresses the Europeans unjustifiable hatred of Africans (Grah Mel 2003: 216). Michael Watts describes colonialism as 'The establishment and maintenance of rule, for an extended period of time by a sovereign power over a subordinate or alien of people who are separate from the ruling power' (Watts 2000). However, others emphasize space and territory to define colonialism.

During the colonial era, African territories were first colonized, and then Europeans exploited them. Although the colonial rule period lasted a relatively short time in Africa, Africans were subjected to organized repression. In Côte d'Ivoire, France ruled as a sovereign and political power via the specific mechanisms of colonialism. France profoundly reorganized Côte d'Ivoire's political environment, mode of economic development and social hierarchies (Conroy 2010). In addition, France forced unnatural boundaries in Côte d'Ivoire and required people to live in new environments without taking into account their life styles (Conroy 2010). Initially, the country's north which includes Odiénné, Kong, Touba and Dabakala was considered as part of French Sudan (which is now called Mali); by January 1900, this segment belonged to Côte d'Ivoire (Ahipeaud 2009: 21-57).

Soon after the Berlin conference of 1885, France sought to politically control West Africa including Côte d'Ivoire and Equatorial Africa. As Tordoff pointed out, the French divided each colony into cercles for better management, based on the 'direct rule' system. A political officer managed each cercle, firing traditional rulers, and replacing them with soldiers or retired government clerks (Tordoff 2002: 27).

By 1916 the French fully controlled Côte d'Ivoire. To further consolidate its power, the French organized the land into districts. French Commanders controlled the districts under the colonial government. Although subjects of the French government, the Ivorians were denied French citizenship. Thus, the French expected them to do public labour, and to join the French military, but denied them fair judicial rights and frequently subjected them to unfair trials. In this way, 
the French marked the beginning of the transformation of Ivorian politics and society (Schaeder 2004: 50).

Furthermore, colonial administrators used the principles of forced labour during the colonization era, insisting on applying pressure, coercion, and the use of force. As Conklin stated:

Colonization rule rests on an act of violence. Its only justification lies in the intention to substitute a more enlightened authority for the one in place, one capable of bringing the conquered peoples to a better existence... The result can only be achieved by applying pressure to individual actions. Such pressure is legitimate, on the sole condition that it is in the best general interests as well as in that of the natives (Conklin 1998: 419-442).

Modern Côte d'Ivoire was born after French colonization. Shortly after the Berlin conference, attended by all the European superpowers, France acquired the West African territories. Côte d'Ivoire became a French colony in 1893 due to the work of Gustave Binger, who was supported by a French trader by the name of Marcel Treich-Laplène, with whom he met secretly to plot colonization. During their mission, the two men travelled from Kong, now northern Côte d'Ivoire, to the south where they signed treaties. In recognition, Paris appointed Binger the first Governor of Côte d'Ivoire.

The project of civilizing the natives, by carrying out the mission civilisatrice, became a key aspect of the colonial era. Indeed, for the colonial master, French culture was universalistic, the French civilization was exportable and the savages should be prepared to embrace it. Like most of the European great powers, the French Colonialists became convinced of the political as well commercial need for expansion. They also remained convinced of their right to rule and share the benefits of civilization to those whom they civilized. In Côte d'Ivoire, that was not the case (Aldrich 2008). The Ivorians paid a high price for France's civilizing work.

\section{THE RESISTANCE TO COLONISATION}

France, which was present at the coast in 1843, returned with a mission: to conquer the interior area. To achieve this mission, Arthur Verdier, Marcel Treich-Laplène who was a French trader and LouisGustave Binger, a military officer, were sent as representatives.

Actual colonization, including establishing a new political, administrative and economic system of management, proved to be a hard exercise. From the beginning when the first measures of the colonial 
administration, namely the establishment of the taxation system was introduced, many locals felt considerable anger towards the French. In 1852, the people of Akapless in the south, who opposed French accumulation of territories and taxation, rebelled. This uprising met with defeat so severe that it allowed Captain Faidherbe to build forts in the south both at Dabou and Grand-Bassam. In an ultimate irony, recruited local chiefs worked alongside the French colonialists within the colonial bureaucracy. Like their twentieth-century counterparts, they also held positions of lower ranks and were tasked to do the dirty work of collecting taxes across the land, following the rules of the colonialists (Edie 2003: 51).

The first real confrontation between the colonial power and the natives started in 1898. When France, one of the world's most advanced democracies with its liberal regime, attempted to forcibly conquer, pacify and administer the land, the natives resisted (Ahipeaud 2009: 23; Conklin 1998: 419-442; Gordon A. and Gordon D. 2001: 32). People from the south of Côte d'Ivoire who opposed the taxation system and genuinely believed in the idea of independence rebelled. For example, in 1910, the Abé people rebelled against the French and in 1915, local resistance intensified when people from the Bété and Baoule ethnic groups joined the rebellion against the French authorities which caused a devastating conflict. The Baoulé played an important role in the twentieth-century history of Côte d'Ivoire, waging the longest resistance war to French colonization. I conducted interviews in Côte d'Ivoire in 2012. Some respondents suggested that many Africans strongly supported Baoulé due to their strong opposition to colonialism. This likely, explains a long Baoulé dominance of Côte d'Ivoire's politics.

Harrism, a large protestant religion begun by Liberian preacher William Wade Harris, also served as a form of resistance (Ahipeaud 2003). Harris walked bare foot from his native Liberia to Côte d'Ivoire and Ghana between 1910 and 1914, preaching his extremely effective evangelical revival based on prophecy, healing and miracles. Harris' first mission landed in Côte d'Ivoire in 1895 and he was particularly successful due to strong presence of Christianity in the area. Harris was arrested and beaten in Kraffy, Côte d'Ivoire on his way back from Ghana with three women assistants, and they were expelled from Côte d'Ivoire towards the end of 1914. The French imprisoned Harris at Cape Palmas 'out of fear of uncontrolled charisma'. Nonetheless, his arrest did not prevent many of his supporters from visiting him. The French empire believed because of his power over the people, Harris might foment rebellion. They extra- 
dited Harris to Liberia in 1915 as a potential 'instigator of revolt' and he died there in 1929 (Ducan and Bakuzufu 2013).

As Ahipeaud (2003) indicated, for imposition of colonial rule, the colonial forces of governor Angoulvand used violent repression against indigenous opponents of French colonialism in order to join their colonies from the north to the coast. Consequently, Angoulvand denied them the opportunity to enjoy their freedom, but there was resistance.

Although resistance occurred, France took advantage of regional conflicts to implement its policy of divide - and - conquer (Schaeder 2004: 59). France used the same divide - and - conquer tactic to interfere with the traditional leadership. For example, France gave employment preference to specific groups, aiming to create competition among them and increase insecurity and conflict. It must be noted that groups from the coast where French originally settled and where the first schools were built were more likely to be chosen for employment (Edie 2003: 48-50).

\section{GOVERNOR ANGOULVAND'S METHOD OF COLONIAL CONTROL}

Realizing that its military method was failing, Paris deployed Governor Angoulvand a civilian with a better colonial ideology. Angoulvand applied his method of 'burnt land' (which became the norm later on [Ahipeaud 2009: 23]). This method consisted of destroying everything where resistance was occurring and imposing heavy taxes to force the local population to join the colonial state (Ahipeaud 2009: 26). When Angoulvand took command of the colony, he made it clear that the new regime would not tolerate the resistance of the locals. For Angoulvand, the country was called la côte des mal gens, the coast of the bad people. This meant that they were unfriendly to foreigners. From Angoulvand's perspective, to administer a territory meant: imposing a few rules, limiting particular privileges for everyone's benefit and collecting more taxes (Angoulvand 1916: 395).

Angoulvand argued that the territory did not exist and insisted the French administration should be received without conflict. He claimed that colonial domination should be achieved through total submission of the indigenous people to a military regime headed by a senior and strong officer or general with the necessary skills (Ahipeaud 2009: 24).

This suggested that France intended to stay forever. Moreover, according to Angoulvand, brutal repression represented the best way to convince those who were les plus dubitatifs, more dubious about France's objective. Angoulvand imposed French rule by burning hous- 
es, and when necessary, destroying entire villages, successfully using state violence and terror against resisters. Thus, French colonial rule in Côte d'Ivoire was based on coercion, not consent. Under Governor Angoulvand, during 'the pacification' process of Côte d'Ivoire, powerful and huge military striking forces were deployed on the ground to break-up any resistance (Broussalian 2011). As a further weapon against resisters, local leaders' heads were cut off, ridiculed and displayed on poles in public places as real war trophies (Ahipeaud 2009: 24). Despite the large number of Ivorians who died unnecessarily and painfully due to French colonization, the French reportedly utilized less brutal tactics than the Belgian and German colonials (Calvocoressi 1991: 493).

\section{THE IMPACT OF COLONIAL LEGACY}

Colonial legacy in Africa can be described as a combination of political and cultural structures, including a broad range of policies inherited by African founding fathers or whatever was left by the colonial masters, which are still affecting African states and politics.

The 1789 French Revolution emphasized the notions of equality and egalitarianism. Therefore, the French introduced an assimilation policy toward their colonies including Côte d'Ivoire. The key French colonial policy of 'assimilation' facilitated integration of colonial 'subjects' into the French nation through indoctrination into French culture via 'an acculturation system'. As long as the non-citizen African subjects willingly and fully embraced French culture, including achieving fluency in French langue - abandoning Indigenous fetishworship or animism and converting to Christianity or obtaining higher education, they were entitled to fully achieve the status of French citizens (Tordoff 2002: 61). Shockingly, though, by 1936, only 80, 509 Indigenes Citoyens Français (French Citizens of African origin) existed in the entire AOF (McNamara 1989: 36).

In French, these 'converts' were called évolués, literally meaning 'civilized persons, or even forward-looking évolués. Under the policy of assimilation, education was 'the main currency' (Thomson 2004: 16). Houphouët-Boigny and others, for example, graduated from a very limited number of grandes écoles or the most prestigious institutions such as the medical school at Dakar or the federal Ecole Normale William Ponty. Less illustrious institutions such as the teachers colleges in Sudan and Côte d'Ivoire or alma mater of Côte d'Ivoire as well as the veterinary school at Bamako also provided French education. In addition, there were two lycées in Dakar, which granted the equivalent of a Baccalauréat (McNamara 1989: 36). 
Some of the graduates from those institutions continued their political and professional careers in significant decision-making positions. Indeed, William Ponty College and those institutions played a crucial role in the education of some first-generation West African leaders of the inter-war era, such as Houphouët-Boigny. Ponty explained that education represented the most efficient instrument of the civilizing work of the colonial state. He went on to say it imposed on the subjects the notion that they could and must improve their living conditions to have access to key resources. However, was the colonial education helpful?

It is fair to say that the concept of assimilation through education applied only to a select group of state elites (Schaeder 2004). For example, in Côte d'Ivoire in 1947, only twenty-one Ponty graduates, or 'Pontins' were elected to the new territorial assembly, not an extraordinary number. Moreover, opportunities were only available in areas that held French economic interest.

The second systematic problem was Pontins found themselves to be à cheval sur deux civilisations, trapped between the African and the French world. One English commentator named the proud graduates who considered themselves elites 'Black Frenchmen' (Chafer 2007: 437-458).

As one of its chief functions, Ponty College introduced its students to a French lifestyle. One well known ex-Pontin, Mamadou Dia summarised the impact of Ponty on himself, where he tasted modern life for the first time the following way:

The time at Ponty was very important... It was at Ponty that I really came into contact with western life, modern life. Before that, I even did not know how to wear a jacket, trouser or a tie. It was at Ponty that, as part of the school's uniform, I wore a European suit, jacket, tunic and a shirt for the first time... I ate at table for the first time... All those things were new to me (Chafer 2007: 437-458).

Although they made considerable efforts to adopt western culture, most Ponty students were rejected by their French counterparts, and were aware that their peers never recognised them as equals (Tordoff 2002: 61). Therefore, despite assimilation being France's official poli$\mathrm{cy}$, in actuality the French only pretended to assimilate the indigenous people to the métropole. Indeed, for all its apparent generosity, true assimilation rarely occurred. Instead, the indigenous people remained in inferior positions because their French compatriots would never accept or treat them as full and equal citizens, although the French stated that Africans including Ivorians were of equal worth to them as 
long as they were cultured as the French were (Schaeder 2004: 61). Despite the assumption of culture superiority, McNamara has argued that the French longstanding commitment to assimilate local populations was a reflection of their inclination to accept them as equals, people who were fluent in French (McNamara 1989: 127).

During the 1879 French Revolution, missionaries were encouraged to spread their language, culture, and political philosophy to the less fortunate non-francophone. This suggested that French civilization missionaries were ethnocentric and automatically assumed French superiority (McNamara 1989: 34). Under the assimilation policy, the French presumed the superiority of the French culture and civilisation. The French project of 'civilising the savages' served as a key justification for the colonial enterprise, and thus the French believed they had a duty to civilise African 'barbarians and turn them into French.'

One can argue that the assimilation policy was purely for the elites who were forced to deny their 'Ivorianness' while embracing a new French culture which was irrelevant to the challenges of leadership and development in Côte d'Ivoire during the post-colonial era. Colonial education did not prepare those who received it for leadership. It is true, in addition to this that it failed to target the solution of economic and social problems of newly independent French African countries including Côte d'Ivoire.

According to Juan Linz, 'authoritarian regimes are political systems with limited, not irresponsible political pluralism with neither intensive nor extensive political mobilisation, and in which a leader or a small group exercises power, within formally ill-defined limits but actually predictable ones' (Ezrow and Frantz 2011: 2). Similarly, Samuel Huntington has indicated that 'authoritarian regimes are characterized by a single leader or small group of leaders with either no party or a weak party, little mass mobilisation, and limited pluralism'.

As A. Gordon and D. Gordon (2001: 48) argued 'Whenever and wherever colonial rule was established, it was essentially a paternalistic, bureaucratic dictatorship'. Based upon his controversial approach to leadership, Governor Angoulvand helped to insure a tradition of civilian authoritarian regime in Côte d'Ivoire that went unchecked for many years because of the conditions he created. The colonial state that was born and developed under Angoulvand became more and more repressive over the years (White 2007: 663).

After independence from France on 7 August, 1960, HouphouëtBoigny became the country's first President. He also insured a tradition of civilian authoritarian regime in Côte d'Ivoire. Until the 1990 election, 
Houphouët-Boigny was the sole candidate at every election held in Côte d'Ivoire. His political party, the Democratic Party of Côte d'Ivoire was the only legal political party until 1990. According to Ahipeaud, the sole political objective of Houphouët-Boigny was to make himself the absolute master of the Ivorian political system (Ahipeaud 2009: 4355). Although from the onset, Houphouët-Boigny had symbolized the politique d'ouverture, an inclusive political process, he suppressed all types of opponents under the firm grip of the one-party state through the PDCI.

As a result, Houphouët-Boigny's presidency largely 'contributed to the weakening of existing fragile structures within the military, the judiciary as well as the civil service' (Bratton and van de Walle 1997: 61-66). However, in today's crisis the successors of HouphouëtBoigny (Henri Konan Bédié, Robert Guëi, Laurent Gbagbo and Alassane Ouattara) have carried on the 'Big Man' tradition, as their respective governments had the reputation of suffering from problems of poor governance and corruption.

Like many post-independent countries of sub-Saharan Africa, Côte d'Ivoire under the leadership of Ivorian elites is still characterized by some form of neo-patrimonialism and personal rule. Although in theory respective regimes were expected to go ahead with the full development of the Ivorian institutions, in practice, they manipulated Ivorian resources, accumulated their fortunes, and consolidated their powers. However, the nation's trajectory of development would have been more positive if the French were not involved in disseminating institutions aimed to encourage, sustain, and protect French economic and political interests.

It should be noted that the French colonizers contributed to the change of the Ivorian economy, which was initially based on subsistence with each village being self-sufficient. However, influenced by the French colonizers, the Ivorian farmers who were denied the right to use free labor began to grow huge crops such as cocoa and coffee. For example, one should also point that in the economic sphere France failed to build any sort of infrastructure or provide the Ivorians with an economic strategy which would sustain them after gaining independence; meanwhile, three French banks shared this important Ivorian market.

Firstly, the Société Générale, renamed Société Générale de Banques de Côte d'Ivoire (SGBCI), the Crédit Lyonnais. Secondly, its subsidiary Société Ivoirienne de Banque (SIB) controlled the Ivorian economy in the 1960s. Finally, there was the Banque Nationale de 
Paris, a subsidiary of Banque Internationale pour l'Industrie et le Commerce de la Côte d'Ivoire (BICICI). At the same time, the French enterprises controlled the bulk of the Ivorian assets.

Moreover, France was the major provider of senior managers to Côte d'Ivoire, both in the government and private sector. However, after independence most French assets in the industrial sector decreased by half within 15 years shifting from 100 per cent in 1960 to 41 per cent in 1976 due to the policy of 'Ivoirisation', designed to provide work for the Ivorians (Ahua 2005: 85). As a result, French influence became less and less important. In the 1980s, the continuing decline in the prices of commodities such as cocoa and coffee caused a massive departure of French entrepreneurs.

However, the devaluation of the CFA Franc in 1994, which was pushed by the French government, and the SAPs imposed by the IMF and the World Bank in the 1990s enabled French investors to restart capital investments in Côte d'Ivoire. Companies, which were nationalized after the independence, were privatized. This was due to the opening up of capital in paragovermental sectors such as water, electricity and telecommunications, allowing French companies to retain numerous and important stakes in the Ivorian economy and reinforce their presence in Côte d'Ivoire.

This neo-colonial system is a mighty obstacle preventing Côte d'Ivoire from experiencing meaningful development. Even today, the effect of French post-colonial rule on Côte d'Ivoire's politics, economics, and social life is still notable. For example, while the France-Côte d'Ivoire economic relationship mainly contributed to the increase of the number of individual French entrepreneurs as well as the French economy, Côte d'Ivoire suffers from underdevelopment and lack of resources. In addition, the nation lacks good governance and faces corrupt institutions and ethnic violence.

\section{CONCLUSION}

This article has outlined Côte d'Ivoire's pre-colonial history and France's acquisition and administration of one of its West African colonies. It has argued that France justified its colonization of Côte d'Ivoire by its desire to civilize its people whom it considered as uncivilized. It has also traced Côte d'Ivoire's path to independence. Drawing upon the background, this article has examined the impact of colonial legacy. Despite the nation being independent since 1960, Côte d'Ivoire is still dealing with the colonial legacy such as the dissemination of French institutions aimed to encourage, sustain, and protect French economic and political interests. 
In 1960, France finally granted independence to Côte d'Ivoire but intended to retain influence. Through a series of deals signed with this newly independent nation, based upon close relations formed during the colonial era, France successfully managed to preserve its strong position in Côte d'Ivoire for decades.

The current state of almost all French West African countries is essentially determined by the history of their occupation. In the case of Côte d'Ivoire, colonization processes such as the 'colonial direct rule' was cleverly used to control everything from administration, to economic, to culture. French colonization's objective was to make the Ivorian a Black French through the politics of domination and assimilation. These politics left a permanent mark on the minds of the colonized.

Many francophone countries including Côte d'Ivoire have been using the monetary unit (CFA) since 1945. From the outset, one institut d'émission was created for the AOF in order to issue and control the money, led by the Bank of France and the French treasury. An operation account was opened for the region. In 1959, taking into account the political, social and economic changes that occurred in the region due to the move from overseas territories to autonomous republics, the institut d'émission was upgraded to a regional bank, called Banque Centrale des Etats de l'Afrique de l'Ouest (BCEAO), but the central banking function for this institution was essentially limited (McNamara 1989: 110-127).

Today, this operation account continues to play the role of a central mechanism system; all CFA financial transactions must pass through it. In addition, despite 'full sovereignty' in 1960, this operation account based at the French treasury in Paris remains the repository of all French West African franc zone foreign exchange reserves, guaranteeing the unlimited convertibility of the CFA into the Euro (formerly the French franc). However, for most foreigners these monetary arrangements constitute the most valuable aspect of the French colonial legacy for West Africa (McNamara 1989: 11).

\section{REFERENCES}

Ahipeaud, M. J. 2003. Elite ideologies and the Politics of Media. A critical history of Ivoirien Elite ideologies and their Press from the Brazaville conference to the December 24th military coup. Published doctoral thesis, University of London, School of Oriental and African Studies, History Department.

Ahipeaud, M. J. 2009. Côte d'Ivoire: Entre Barbarie et Démocratie. Abidjan: Les Editions du CERAP. 
Ahua, B. 2005. La France se taille la part du point de l'économie Ivoirienne. Manière de voir 79: 85.

Aldrich, R. 2008. The French Empire: Colonialism and its Aftermath. Paper for Comparative Imperial Transformations. The University of Sydney Conference. URL: http://sydney.edu.au/arts/research/nation empire globe/ downloads/Empires_WUN_Aldrich_3_08.pdf (accessed 22 August 2014).

Angoulvand, G. 1916. La Pacification de la Côte d'Ivoire. Méthodes et Résultats Paris: Emile Larouse.

Beck, S. 2010. West Africa and the French: 1700-1950. URL: http://www. san.beck.org/16-9-WestAfricaFrench.html. Accessed August 21, 2014.

Bratton, M., and van de Walle, N. 1997. Democratic Experiments in Africa: Regime Transitions in Comparative Perspective Cambridge: Cambridge University Press.

Broussalian, K. 2011. Overcoming Colonial Vestiges in Côte d'Ivoire and Ghana. Journal of Political Inquiry 4. URL: http://www.jpinyu.com/ uploads/2/5/7/5/25757258/overcoming-colonial-vestiges-in-cote-d-ivoireand-ghana.pdf. Accessed September 23, 2014.

Brunshwig, H. 1964. French Colonialism, 1871-1914: Myths and Realities. New York: Praeger.

Calvocoressi, P. 1991. World Politics since 1945. London and New York: Longman.

Chafer, T. 2007. Education and Political Socialization of a National-Colonial Political Elite in French West Africa, 1936-47. The Journal of Imperial and Commonwealth History 35 (3): 437-458.

Conklin, A. 1998. Colonialism and Human Rights: A Contradiction in Terms? The Case of France and West Africa, 1895-1914. JSTOR: American Historical Review 103 (2): 419-442.

Conroy, C. P. 2010. France as a Negative Influence on Côte d'Ivoire: The Consequences of Foreign Interference. Scholars and Senior Theses. Paper 63. URL: http://digitalcommons.salve.edu/pell_theses/63. Accessed May 12, 2012.

Ducan, G., and Bakuzufu, O. U. 2013. Revival Movements and Indigenous Appropriation in African Christianity. Pretoria: The University of Pretoria. URL: http://repository.up.ac.za/bitstream/handle/2263/21579/ 012_Chapter11_p278-308.pdf?sequence=13. Accessed April 10, 2018.

Edie, C. 2003. Politics in Africa A New Beginning? Melbourne: Wadsworth Thomson Learning.

Ezrow, N., and Frantz, E. 2011. Dictators and Dictatorships Understanding Authoritarian Regimes and their Leaders. New York: The Continuun International Publishing Group.

Grah Mel, Frédéric. 2003. Félix Houphouët-Boigny: Le fulgurant Destin d'une Jeune Proie, Les Editions du CERAP, Abidjan. 
Gordon, A., and Gordon, D. 2001. Understanding Contemporary Africa. $3^{\text {rd }}$ ed. London: Lynne Rienner Publishers.

Hatt, C. 2003. The African-American Slave Trade. Hong Kong: WhiteThomson Publishing Ltd.

Lenin, V. 1917. Imperialism, the Highest Stage of Capitalism. First published in pamphlet form in Petrograd, Russia.

Long, L. L. 1998. Present Day Effects of French Colonisation on Former French Colonies. Knoxville: University of Tennessee. URL: http:// trace.tennessee.edu/cgi/viewcontent.cgi? article=1266\&context=utk_chanh onoproj. Accessed August 12, 2014.

McNamara, F. T. 1989. France in Black Africa. Washington DC: National Defense University Press Publications.

Robinson, R., and Gallengher, J. 1961. Africa and the Victorians. London: Macmillan. In Why did Europe Colonise Africa? (n.d). The Saylor Foundation. URL: http://www.saylor.org/site/wp-content/uploads/2011/ 12/HIST252-Subunit-2.3.2-Why-Did-Europe-Colonize-FINAL. Pdf. Accessed October 3, 2013.

Schaeder, P. 2004. African Politics and Society: A Mosaic in Transformation. $2^{\text {nd }}$ ed. Belmont CA: Wadsworth.

Thomson, A. 2004. An Introduction to African Politics. $2^{\text {nd }}$ ed. London: Routledge.

Tordoff, W. 2002. Government and Politics in Africa. $4^{\text {th }}$ ed. New York: Palgrave Macmillan.

Watts, M. 2000. The Dictionary of Human Geography. $4^{\text {th }}$ ed. Oxford and Malden, MA: Blackwell Publishers.

White, O. 2007. Drunken States: Temperance and French Rule in Côte d'Ivoire 1908-1916. Journal of Social History 40 (3): 663-684.

Zouande, S. F. 2011. Governance and Democratic Transition in Africa: Understanding 'Ivoirite' and the Ethnicity Challenges to Citizenship and $\mathrm{Na}$ tion-Building in Côte d'Ivoire. A master thesis submitted to the graduate school, Department of African Studies, Howard University. Ann Arbor, Michigan: ProQuest. 